\title{
Briefs
}

\section{Measurement of AC Parameters of Gallium Arsenide (GaAs/Ge) Solar Cell by Impedance Spectroscopy}

\author{
R. Anil Kumar, M. S. Suresh, and J. Nagaraju
}

\begin{abstract}
Measurement of solar cell ac parameters is important for the design of efficient and reliable satellite power systems. In the present study, the ac parameters of Gallium Arsenide (GaAs/Ge) solar cell have been measured using impedance spectroscopy. The cell capacitance, dynamic resistance, and series resistance were measured. The results show that the transition capacitance $\left(C_{T}\right)$ is dominant up to $0.9 \mathrm{~V}$ and beyond $0.9 \mathrm{~V}$ diffusion capacitance is significant.
\end{abstract}

\section{INTRODUCTION}

The generation of power for space applications, in general, is by solar cells. In an effort to increase the conversion efficiency of solar cells, new materials and technologies are being developed. Of late, the use of Gallium Arsenide (GaAs) solar cells is being used in many spacecrafts. To design an efficient, reliable, high power and small size switching power conditioner a thorough understand of both static (dc) and dynamic (ac) characteristics (especially capacitance) of the solar cells are necessary. The static current-voltage $(I-V)$ characteristics of $\mathrm{GaAs} / \mathrm{Ge}$ solar cells are generally measured by the manufacturers and are well understood. However, the ac characteristics of these cells have not received much attention.

The equivalent circuit (both dc and ac) of a solar cell is shown in Fig. 1(a) and (b). The diode is assumed ideal and hence, the static characteristics of a solar cell are not a function of the frequency. The ac equivalent circuit of a solar cell is obtained by replacing the diode by its capacitance (diffusion capacitance $\left(C_{d}\right)$ and transition capacitance $\left(C_{T}\right)$ in parallel) and dynamic resistance $\left(R_{d}\right)$ in parallel with shunt resistance $\left(R_{T}\right)$.

In this brief, the ac characteristics of a GaAs/Ge solar cell at different cell voltages and at room temperature are presented. The experimental values are compared with theoretical values.

\section{EXPERIMENTAL SETUP}

Impedance spectroscopy has been employed for the measurement of ac parameters of a GaAs/Ge solar cell. The test setup consists of an electrochemical interface (ECI) and a frequency response analyzer (FRA) [1]. The measurements were carried-out on a GaAs/Ge solar cell $\left(20 \times 40 \mathrm{~mm}\right.$ size) at room temperature of $22{ }^{\circ} \mathrm{C} \pm 1{ }^{\circ} \mathrm{C}$, under dark condition by biasing the cell at the different voltages between $0.3 \mathrm{~V}$ and $0.9 \mathrm{~V}$ in steps of $0.1 \mathrm{~V}$ and also at 0.87 and $0.95 \mathrm{~V}$. The amplitude of the ac signal was $10 \mathrm{mV}$ with the frequency ranging from $1 \mathrm{~Hz}$ to $60 \mathrm{kHz}$.

\section{RESULTS AND DISCUSSION}

The impedance spectrum of GaAs/Ge solar cell at $0.3 \mathrm{~V}$ and $0.95 \mathrm{~V}$ are shown in Fig. 2(a) and (b), respectively. It shows that the spectrum

Manuscript received February 6, 2001; revised April 9, 2001. The review of this brief was arranged by Editor P. N. Panayotatos.

R. Anil Kumar and M. S. Suresh are with ISRO Satellite Centre, ISRO, Bangalore 560 017, India (email: ranil@isac.ernet.in).

J. Nagaraju is with the Department of Instrumentation, Indian Institute of Science, Bangalore 560 012, India.

Publisher Item Identifier S 0018-9383(01)07332-4.

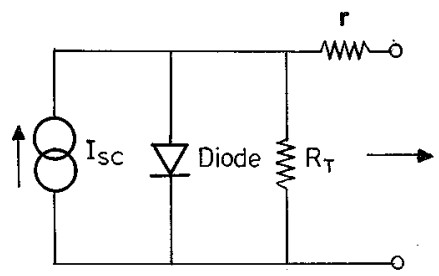

(a)

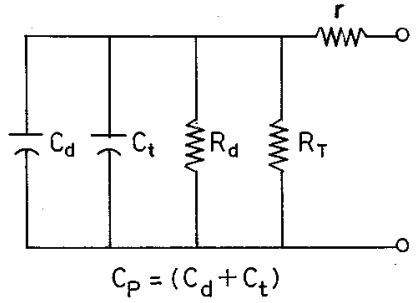

(b)
Fig. 1. (a) The dc equivalent circuit and (b) ac equivalent circuit of a solar cell.
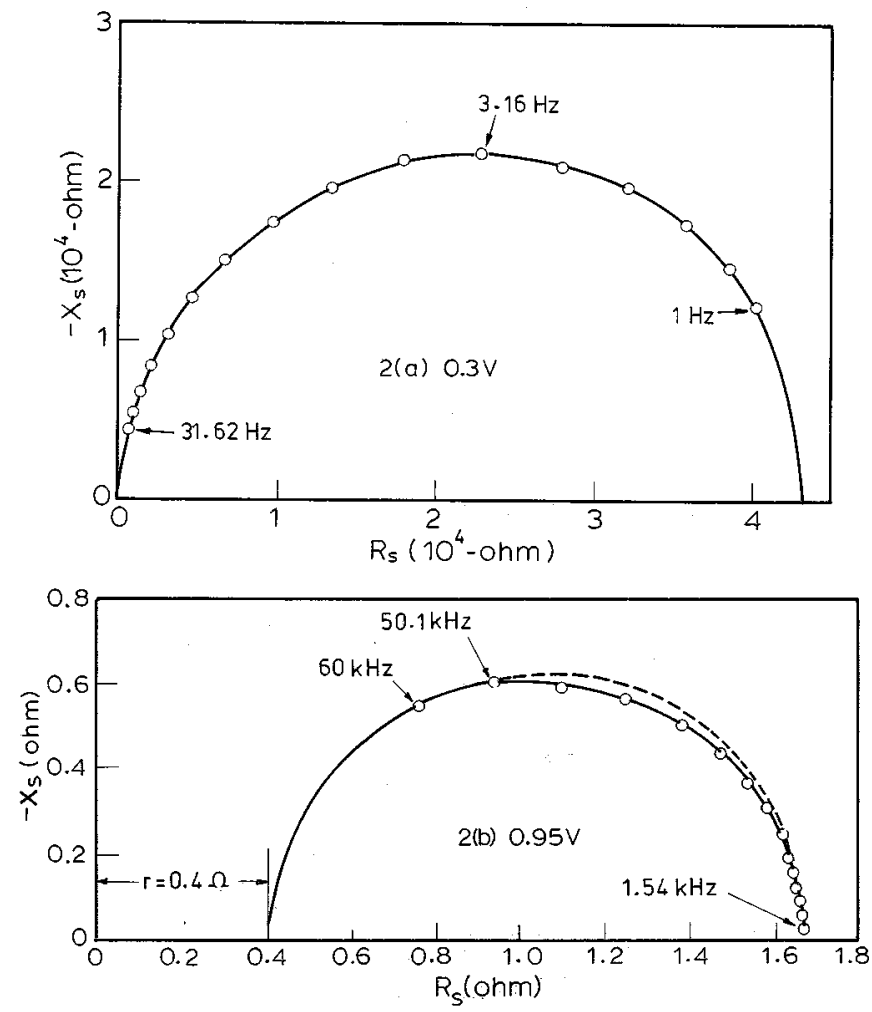

Fig. 2. Impedance spectrum of GaAs/Ge solar cell at (a) $0.3 \mathrm{~V}$ and (b) $0.95 \mathrm{~V}$.

is a semicircle indicating that the ac equivalent circuit of a solar cell is a resistance and a capacitance in parallel with a single time constant. At $0.95 \mathrm{~V}$ the semicircle is slightly shifted along the real axis, indicating that the magnitude of the cell impedance is comparable to its series resistance $(r)$. It is observed that the frequency at which maximum reactance occurs shift to higher frequencies as the cell operating voltage is increased. The measured value of cell current and calculated values of cell capacitance and resistance are shown in Table I for different cell voltages $\left(V_{d}\right)$. The variation in cell capacitance and resistance with cell voltage are shown in Figs. 3 and 4, respectively.

The transition capacitance of a solar cell with abrupt junction is given by [2]

$$
C_{t}=\frac{B}{\left(V_{0}-V_{d}\right)^{1 / 2}} \quad \text { for an abrupt junction }
$$




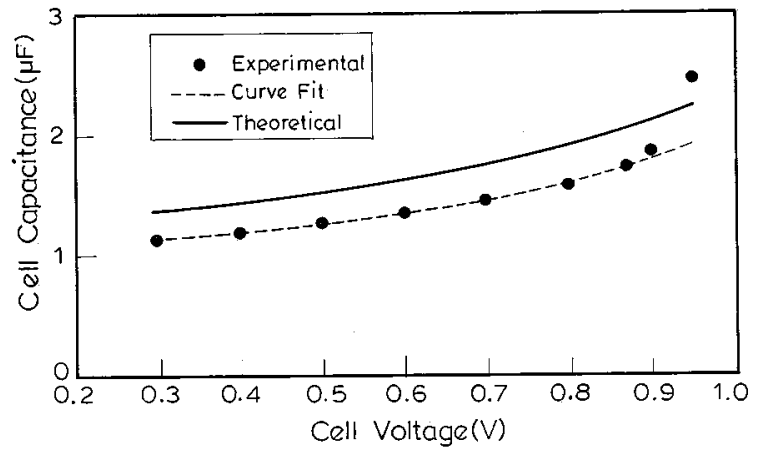

Fig. 3. Comparison of cell capacitance (experimental, curve-fit, and theoretical) at different cell voltage $\left(V_{d}\right)$.

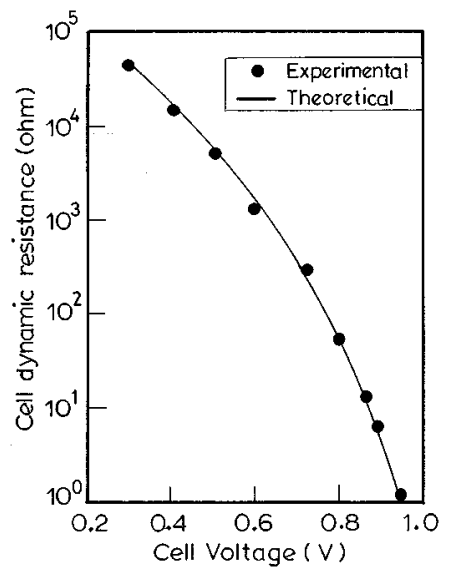

Fig. 4. Comparison of cell resistance (experimental and theoretical) at different cell voltage $\left(V_{d}\right)$.

where

$B$ constant;

$V_{0} \quad$ junction voltage;

$V_{d}$ applied voltage.

Substituting the measured capacitance values of the cell operating voltage (at 0.3 and $0.7 \mathrm{~V}$ ) and cell capacitance $(1.13 \mu \mathrm{F}$ and $1.46 \mu \mathrm{F})$ in (1), the values of $V_{0}$ and $B$ are $1.3 \mathrm{~V}$ and $1.13 \times 10^{-6}$, respectively.

Taking these two values of $V_{0}$ and $B$, cell capacitance (curve-fit) at other cell voltages was calculated as shown in Fig. 3, along with measured capacitance. Here, the variation in cell capacitance with the cell voltage follows (1), which confirms that the capacitance of a $\mathrm{GaAs} / \mathrm{Ge}$ solar cell is largely due to transition capacitance $\left(C_{T}\right)$ for an abrupt $\mathrm{p}-\mathrm{n}$ junction up to about $0.9 \mathrm{~V}$. Beyond $0.9 \mathrm{~V}$ diffusion capacitance $\left(C_{d}\right)$ tends to take over. From the doping levels of "n" and "p" regions [2]

$$
\begin{aligned}
V_{0} & =V_{T} \times \ln \left[\left(N_{A} \times N_{D}\right) / N_{i}^{2}\right] \\
B & =A \sqrt{\frac{e N \varepsilon_{0} \varepsilon_{r}}{2}}
\end{aligned}
$$

where

$$
N=\frac{N_{A} N_{D}}{N_{A}+N_{D}}
$$

and

$V_{T} \quad \mathrm{kT} / \mathrm{e} \sim 0.025 \mathrm{~V}$ at $22{ }^{\circ} \mathrm{C}$;

$k \quad$ Boltzman constant;

$T \quad$ temperature in Kelvin;

e electron charge $=1.6 \times 10^{-19} \mathrm{C}$;
TABLE I

VARiation of Solar CEll aC PARAMETERS With CEll Voltage

\begin{tabular}{c|c|c|c}
\hline $\begin{array}{c}\text { Cell Voltage } \\
V_{\mathrm{d}} \text { Volts }\end{array}$ & $\begin{array}{c}\text { Cell Current } \\
\text { I }\end{array}$ & $\begin{array}{c}\text { Cell Capacitance } \\
C_{\mathrm{P}} \mu \mathrm{F}\end{array}$ & $\begin{array}{c}\text { Dynamic Resistance } \\
\mathrm{R}_{\mathrm{P}} \Omega\end{array}$ \\
\hline 0.3 & $2.0 \mu \mathrm{A}$ & 1.13 & 43,800 \\
\hline 0.4 & $6.5 \mu \mathrm{A}$ & 1.18 & 14,570 \\
\hline 0.5 & $17.3 \mu \mathrm{A}$ & 1.26 & 5,116 \\
\hline 0.6 & $60.0 \mu \mathrm{A}$ & 1.34 & 1,310 \\
\hline 0.7 & $0.24 \mathrm{~mA}$ & 1.46 & 282 \\
\hline 0.8 & $1.20 \mathrm{~mA}$ & 1.57 & 52.0 \\
\hline 0.87 & $4.06 \mathrm{~mA}$ & 1.77 & 12.5 \\
\hline 0.9 & $7.09 \mathrm{~mA}$ & 1.86 & 6.4 \\
\hline 0.95 & $23.43 \mathrm{~mA}$ & 2.45 & 1.2 \\
\hline
\end{tabular}

$N_{i} \quad$ intrinsic concentration of electrons and holes for the base semiconductor $=1.79 \times 10^{12} \mathrm{~m}^{3}$ at $25^{\circ} \mathrm{C}$;

A area of solar cell $=8 \times 10^{-4} \mathrm{~m}^{2}$;

$* \varepsilon_{r} \quad$ relative permitivity of material $=13.1$;

$\varepsilon_{o} \quad$ permitivity of free space $=8.854 \times 10^{-12} \mathrm{~F} / \mathrm{m}$;

${ }^{*} N_{A} \quad$ doping concentration in $P$ region $=1 \times 10^{24} / \mathrm{m}^{3}$;

${ }^{*} N_{D} \quad$ doping concentration in $N$ region $=5 \times 10^{23} / \mathrm{m}^{3}$.

* based on the manufacturer's data.

Substituting these values in (2)-(4), $V_{0}=1.34 \mathrm{~V}, B=1.41 \times 10^{-6}$ are obtained. The transition capacitance calculated using theoretical values of $V_{o}$ and $B$ are shown in Fig. 4, with curve-fit and measured cell capacitance.

The following observations are made from Fig. 3:

a) The measured cell capacitance is lower than the theoretical value. This could be due to the variations in the information available from the manufacturers.

b) The measured cell capacitance deviates from the curve-fit cell capacitance beyond $0.9 \mathrm{~V}$ as the minority carrier injection level is high [3] and diffusion capacitance becomes significant.

Another observation is that the impedance spectrum of the solar cell close to open circuit is not a perfect semicircle [Fig. 2(b)]. At these voltages, the cell resistance is comparable to the series resistance $(r)$ of the solar cell and a distributed parameter modeling is necessary, rather than a lumped model to represent the cell behavior more accurately [4]. However, the effect of this on cell value of the capacitance measured is not large.

Another important ac parameter of the solar cell is its parallel resistance $\left(R_{p}\right)$. It is the parallel combination of shunt resistance $\left(R_{t}\right)$ and the dynamic resistance $\left(R_{d}\right)$. In general the value of $R_{t}$ is very large when compared with $R_{d}$ around open circuit condition, hence parallel resistance is approximately equal to $R_{d}$. However, near short circuit region $R_{d}$ becomes large and $R_{p}$ is nearly equal to $R_{t}$. The dynamic resistance $\left(R_{d}\right)$ is given by [2]

$$
R_{d}=\frac{V_{T} \eta}{I}
$$

where $\eta=$ diode factor (value depends on the generation of electron hole pairs in the transition region) $I=$ cell current.

Using (5), $R_{d}$ is calculated for various cell voltages $\left(V_{d}\right)$, taking the cell current from Table I and with appropriate value of diode factor ( $~ \eta=4$ to 2 to 1 ). The experimental values of cell resistance are in good agreement with calculated cell resistance for (5), as shown in Fig. 4.

\section{CONCLUSION}

The measurement on GaAs/Ge cell shows that the transition capacitance is dominating from short circuit region to $0.9 \mathrm{~V}$. Beyond $0.9 \mathrm{~V}$ the contribution of the diffusion capacitance is about $20-30 \%$ of the total capacitance. The presence of only one time constant in the impedance spectrum indicates that the germanium substrate diode is passive and 
does not contribute to cell impedance. The experimental and curve-fit values are in good agreement confirming the formation of an abrupt junction.

\section{ACKNOWLEDGMENT}

The authors are thankful to Director, ISAC, Deputy Director, ESA, Group Director, Power Systems Group, and General Manager, Facilities, ISAC for providing permission to publish this paper, and Head, Solar Panel Division for providing Gallium Arsenide cells for experimentation. They also thank Deputy General Manager, ETF and Deputy Manager, Shock and Vibration Facility, ISAC.

\section{REFERENCES}

[1] R. A. Kumar, "Measurement of solar cell AC parameters using impedance spectroscopy," M.S. thesis, Indian Institute of Science, Bangalore, India, Jan. 2000.

[2] Millman and Halkias, Integrated Electronics. New York: McGrawHill, 1972, pp. 61-66.

[3] J. J. Liou, Advance Semiconductor Device Physics and Modeling. Boston, MA: Artech House, 1994, pp. 84-87.

[4] A. Zekry and A. Y. Al-Mazroo, "A distributed SPICE-model of a solar cell," IEEE Trans. Electron Devices, vol. 43, no. 5, pp. 691-700, 1996. 